\title{
Factors influencing the use of climate information by Colorado municipal water managers
}

\author{
Jessica L. Lowrey ${ }^{1,3, *}$, Andrea J. Ray ${ }^{2}$, Robert S. Webb ${ }^{2}$ \\ ${ }^{1}$ University of Colorado at Boulder, NOAA, Western Water Assessment, 216 UCB, Boulder, Colorado 80309, USA \\ ${ }^{2}$ NOAA Earth System Research Laboratory, R/PSD1, 325 Broadway, Boulder, Colorado 80305, USA \\ ${ }^{3}$ Present address: 625 Glenwood Drive, Lafayette, Colorado 80026, USA
}

\begin{abstract}
Water supplies in Colorado are sensitive to climate variability. Throughout the study period (2004-2009), there was an increase in demand for climate products and climate education by water management decision makers, which we attribute to a severe drought beginning in 2002 that changed the decision makers' perception of risk. Once decision makers recognized that they were vulnerable to water supply shortages, they sought out information and education from the Western Water Assessment (WWA). Building on relationships established prior to the 2002 drought, the WWA improved the climate literacy of water managers through enhanced interaction, which resulted in an increased use of climate information, outlooks (i.e. seasonal forecasts), and projections in water planning. In addition to the way that climate science can inform decision-making, we documented how decision makers can inform climate science of the need for additional research. In this article, we show the evolution of the use of different types of climate products and explain the connections among drought, perception of risk, climate literacy, and interactions with climate information providers.
\end{abstract}

KEY WORDS: Climate information - Climate products - Climate services - Water management · Western USA · Drought

\section{INTRODUCTION}

Rapid population growth, finite water resources, and increasing climate variability are making the western United States increasingly vulnerable to drought (U.S. Department of Interior 2005). Yet water management decision makers (hereafter 'water managers') have not been taking advantage of all the climate information and forecasts available from the National Oceanic Atmospheric Administration (NOAA) and other federal agencies and research institutions (CCSP 2008). The use of climate information 1 alone cannot decrease a water provider's vulnerability to water shortages; however, historic observations and climate projections at seasonal to decadal time scales can potentially help

1We define 'climate information' as current conditions or historic records of climate-related variables, such as temperature, precipitation, snow water equivalent, streamflow and soil moisture. them prepare for drought. Given the impact of climate on water supplies, the present study was motivated by interest in how climate information providers communicate with municipal water managers, who, in turn, might use the information to better prepare for water supply shortages on interannual and longer (30 to 50 yr) time scales.

Previous studies have shown that 1 or 3 mo seasonal climate outlooks 2 issued by the NOAA Climate Prediction Center (CPC) are hard to locate on the web, are hard to understand, do not address relevant climate variables, and do not represent sufficient skill or lead times (Callahan et al. 1999, Pagano et al. 2001, 2002, Hartmann et al. 2002, Carter \& Morehouse 2003,

\footnotetext{
2The studies cited here use 'climate forecasts' to refer to seasonal climate outlooks, but we use the official NOAA term for the products (O'Lenic et al. 2008). 'Climate outlooks' are projections of temperature and precipitation for months or seasons in the future at the scale of climate divisions.
} 
Table 1. Water providers, population, annual supply, percent of the total population of Colorado (2003). Based on pers. comm. with water managers throughout the study period

\begin{tabular}{|c|c|c|c|c|c|c|}
\hline Provider & $\begin{array}{c}\text { Population } \\
\text { served }\end{array}$ & $\begin{array}{l}\text { Percent of } \\
\text { Colorado } \\
\text { population }\end{array}$ & $\begin{array}{c}\text { Annual } \\
\text { availability/system } \\
\text { yield }\left(10^{3} \mathrm{~m}^{3}\right)^{\mathrm{a}}\end{array}$ & $\begin{array}{c}\text { Reservoir } \\
\text { storage capacity } \\
\left(10^{3} \mathrm{~m}^{3}\right)^{\mathrm{a}}\end{array}$ & $\begin{array}{l}\text { Annual } \\
\text { demand } \\
\left(10^{3} \mathrm{~m}^{3}\right)^{\mathrm{a}}\end{array}$ & $\begin{array}{l}\text { Ratio of } \\
\text { storage: } \\
\text { demand }\end{array}$ \\
\hline Aurora & 289325 & 6.4 & 96090 & 192426 & 49569 & $3.9: 1$ \\
\hline Boulder & 93051 & 2.0 & 29604 & 32071 & 29604 & $1: 1$ \\
\hline Colorado Springs & 370448 & 8.1 & 146787 & 299741 & 98680 & $3: 1$ \\
\hline Denver & 1100000 & 24.2 & 425558 & 830146 & 351548 & $2.4: 1$ \\
\hline Northern ${ }^{b}$ & 750000 & 14.4 & 385099 & 997531 & 286172 & $3.5: 1$ \\
\hline Westminster & 104642 & 2.3 & 37005 & 27754 & 27137 & $1: 1$ \\
\hline Sum & & 57.5 & & & & \\
\hline \multicolumn{7}{|c|}{$\begin{array}{l}\text { a The standard unit of volume for water that is used by the United States water management community is acre-feet. An } \\
\text { acre-foot }\left(1233.5 \mathrm{~m}^{3}\right) \text { is the volume of water that would cover an area of } 1 \text { acre }(0.4 \mathrm{ha}) \text { to a depth of } 1 \text { foot }(30.48 \mathrm{~cm}) \\
\text { b Northern's service area includes the city of Boulder, and Northern's population served includes the same population served } \\
\text { by Boulder. However, the percent of Colorado population shown for Northern does not include Boulder }\end{array}$} \\
\hline
\end{tabular}

Gamble et al. 2003, Rayner et al. 2005, Steinemann 2006). These studies suggested that water managers would be more likely to incorporate that information into their operational models if forecasters produced evaluations of seasonal climate outlooks that water managers could understand, and combined climate outlooks with streamflow forecasts that intersected with the existing knowledge base of water managers (Pagano et al. 2001, 2002, Hartmann et al. 2002, Huppert et al. 2002, Carter \& Morehouse 2003, Gamble et al. 2003, Rayner et al. 2005, Steinemann 2006). In addition, these studies suggested that increased communication between forecasters and water managers was necessary for water managers to appreciate the utility of climate outlooks and for climate scientists to recognize the uses and needs of forecasts by water managers (Callahan et al. 1999, O'Conner et al. 1999, Pagano et al. 2001, 2002, Hartmann et al. 2002, Huppert et al. 2002, Carter \& Morehouse 2003, Gamble et al. 2003).

These previous studies focused on the following regions of the United States ${ }^{3}$ : Pennsylvania $\left(\mathrm{O}^{\prime}\right.$ Conner et al. 1999), the Pacific North West (Callahan et al. 1999, Rayner et al. 2005), Arizona (Pagano et al. 2001, 2002, Carter \& Morehouse 2003), California (Rayner et al. 2005), Washington, D.C. (Rayner et al. 2005), and Georgia (Steinemann 2006). However, these studies were not directly applicable to Colorado because several climatological and societal factors distinguish the state from previous study regions. In Colorado, water managers have both an established relationship with climate scientists and experience with a recent drought. In addition, the previous studies looked only

${ }^{3}$ Six independent studies with distinct time periods and groups of managers were carried out; several additional papers were written that reference or build on these 6 studies. at the use of climate outlooks in annual water management operations, whereas the use of climate information, seasonal climate outlooks, and climate change projections $\mathrm{s}^{4}$ in both annual and long-term (30 to $50 \mathrm{yr}$ ) decision processes is also important in Colorado.

This study focuses on 6 water providers along the Front Range of Colorado, an area that extends about $160 \mathrm{~km}$ ( 100 miles) along the eastern side of the Rocky Mountains from Fort Collins in the north to Colorado Springs in the south; 5 of the water providers are affiliated with cities: Aurora Water (Aurora), the City of Boulder Water Utility (Boulder), Colorado Springs Utilities (Colorado Springs), Denver Water (Denver), and the City of Westminster Water Resources and Treatment Division (Westminster); the last water provider is a conservancy district: Northern Water (Northern) $)^{5}$. Together, these organizations provide water to about $60 \%$ of Colorado's population (Table 1).

The present study sought to identify the uses and needs for climate information, outlooks, and projections among the 6 large water providers in Colorado and to evaluate the factors affecting annual and longterm decisions. Our study period started after the severe drought in 2002, which caused water managers to rethink their long-term supply plans. We evaluated how the drought affected and possibly changed water management decisions and highlighted why Colorado is unique in terms of water management challenges and adaptation to climate.

\footnotetext{
${ }^{4}$ Climate change projections are the output from general circulation models (GCMs) that provide climate scenarios for 50 to $100+\mathrm{yr}$ in the future for large-scale areas (300 km grids). ${ }^{5}$ Northern, Colorado's first water conservancy district, provides water for agricultural, municipal, domestic, and industrial uses in northeastern Colorado; 33 towns and cities own shares in Northern Water, including the city of Boulder.
} 


\section{BACKGROUND}

Our study capitalized on an ongoing iterative process of communication and education between Western Water Assessment (WWA) and municipal water managers in Colorado. WWA was initiated in 1999, as the third of 10 Regional Integrated Sciences and Assessments (RISAs) now funded by NOAA. WWA was established with the purpose of identifying regional vulnerabilities to climate variability and change and the goal of developing products that will help water managers in the Intermountain West (Colorado, Wyoming, and Utah) adapt to this change. Through research, education, and communication efforts over the last decade, WWA has fostered relationships between water managers and scientists in order to educate water managers about the available climate information and forecasts and to help NOAA develop climate products useful to water managers (http://wwa.colorado.edu).

The State of Colorado developed a means of disseminating information on drought conditions with the establishment of the Water Availability Task Force (WATF) in 1981. Since then, WATF meetings have been held at least 3 times annually, and monthly in times of drought. At WATF meetings, representatives from the State Climatologist's Office, the Natural Resources Conservation Service (NRCS), the State Engineer's Office, the Bureau of Reclamation, and NOAA provide information on observations and forecasts of water supply, snowpack, precipitation, and streamflows. Scientists affiliated with WWA are also involved with the WATF, typically presenting seasonal climate outlooks and contributing to assessments of drought conditions.

The most recent drought conditions in Colorado began in 2000 and intensified in 2002. The present study documents the increased occurrence of water providers' interest in climate outlooks, projections, and other climate information after that turning point. Prior to the 2002 drought, representatives from water providers did not regularly attend the WATF meetings; most attendees were primarily from state and federal agencies. Water managers began regularly attending the WATF during the 2002 drought (Fig. 1), and, since then, the WATF has become an important source of climate and water supply information for the 6 Colorado Front Range water providers included in the present study.

The bulk of the annual water supply in Colorado comes from spring runoff of snowpack, which represents between 50 and $70 \%$ of the annual precipitation in the mountainous regions of the state (Serreze et al. 1999, Hunter et al. 2006). The IPCC (2007b) defines sensitivity as 'the degree to which a system is affected, either adversely or beneficially, by climate variability or change.' We define the sensitivity of water supplies to climate variability as the 'impact of natural variability of streamflows on annual water availability.' Thus, while sensitivity to climate variability can be hard to quantify, most water supplies in Colorado are inherently sensitive to climate variability, due to variations in the winter snowpack (which dominates water supplies), recent and anticipated population growth, and fully appropriated rivers (Nichols \& Kenney 2003). Water managers have used current and historic climate information and streamflow forecasts ${ }^{\underline{6}}$ to prepare for interannual variability in supplies.

Colorado water providers rely on reservoirs to store spring runoff and ensure an adequate water supply all year long. Thus, water availability is based on both the quantity of water in the streams and aquifers and on the ability to divert, store, and use that water. The water management community distinguishes between water supplies in streams and rivers and water that is available to divert and use. 'Water supply' is water in all states of the hydrologic cycle (except water vapor): rain, snow, streamflows, soil moisture, and groundwater. 'Water availability' includes only the fraction of the water supply that is accessible and sufficient to meet demands. Thus, each water provider has a different amount of water available based on water rights and storage potential (Table 1). Whereas there are $3 \mathrm{com}$ mon definitions of drought (meteorological, hydrological, and agricultural) (Pielke et al. 2005), water managers generally define drought as: when water availability is not sufficient to meet demand (without enforcing water use restrictions) on an annual basis. A water provider whose annual water availability is more sensitive to climate variability relative to that of other providers is more vulnerable to water shortages and drought. The water providers in the present study represent a range of sensitivities and abilities to meet demands in times of water shortages.

The variability and timing of precipitation supplying water basins, water rights priorities, and the ratio of average storage to annual demand influence the sensitivity of water supplies to climate variability. Most rivers in Colorado are dependent on runoff from spring snowmelt in the mountains for much of their streamflow. The degree to which a stream experiences large seasonal variability increases with its proximity to the Continental Divide. In addition, the topography and elevation in Colorado contribute to variations in winter snowfall and the resulting annual water supplies across the different river basins (Ray et al. 2008). For

\footnotetext{
6'Streamflow forecasts' are distinct from climate outlooks because they are projections of a unique parameter that is influenced by climate variables like temperature and precipitation.
} 
Use of climate information

Water managers do not use climate information and outlooks in operations or long-term plans and use the historic record of hydrology in annual operations. Climate change is no considered.

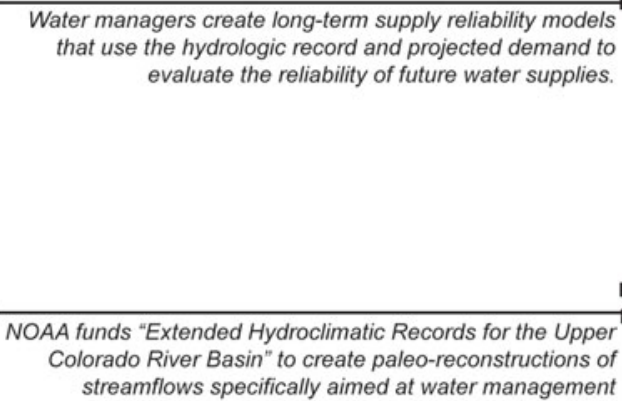

Water managers create long-term supply reliability models that use the hydrologic record and projected demand to evaluate the reliability of future water supplies.

NOAA funds "Extended Hydroclimatic Records for the Upper Colorado River Basin" to create paleo-reconstructions of streamflows specifically aimed at water management

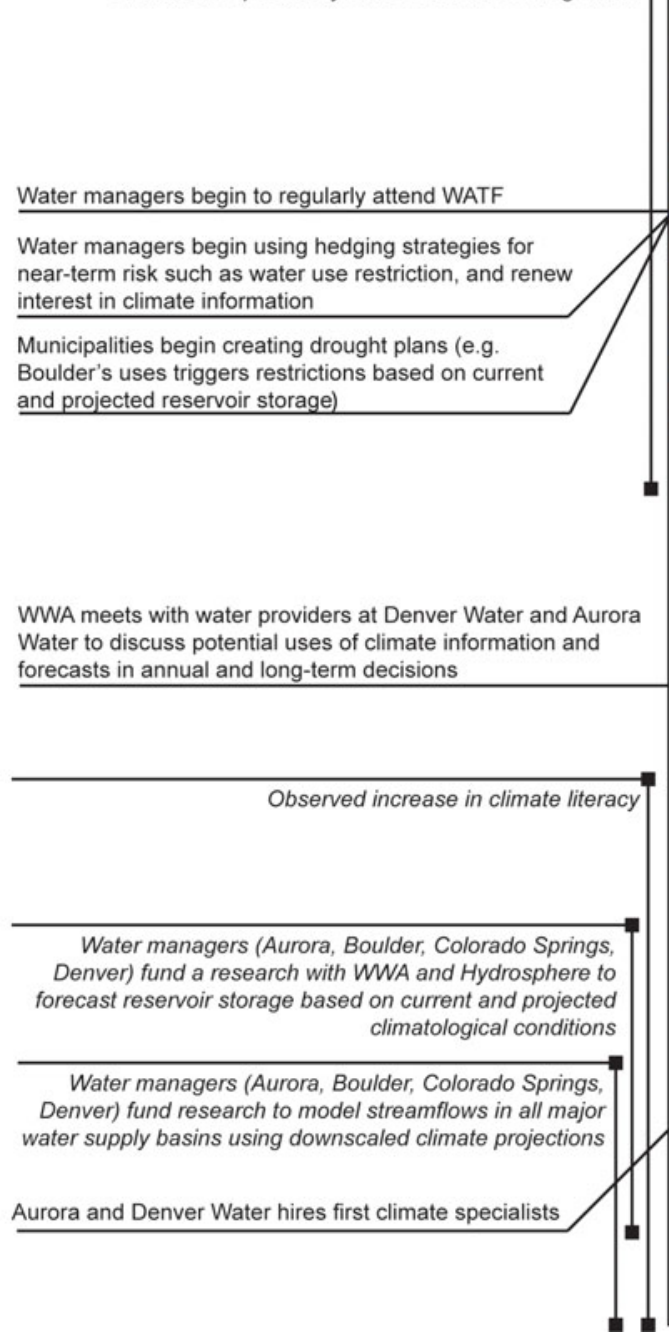

\section{Climate literacy}

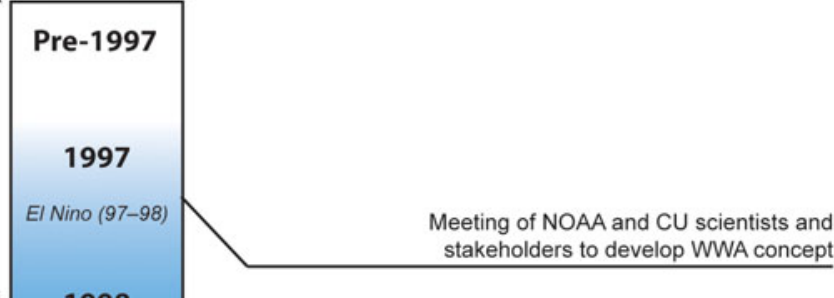
Colorado Water Conservation District

2004

2002

Drought (2002)

2003

WWA regular WWA is created and establishes participation in connections with key water management Colorado WATF communities in Colorado

2000

2001

2006

2007

Water supply shortage across Colorado; all Front Range water providers enforce ourdoor water use restrictions

WWA produces climate information sheets as a rapid response to 2002 drought

WA has first workshop for water managers. Focus is on seasonal forecast use.

2005 workshop for water managers

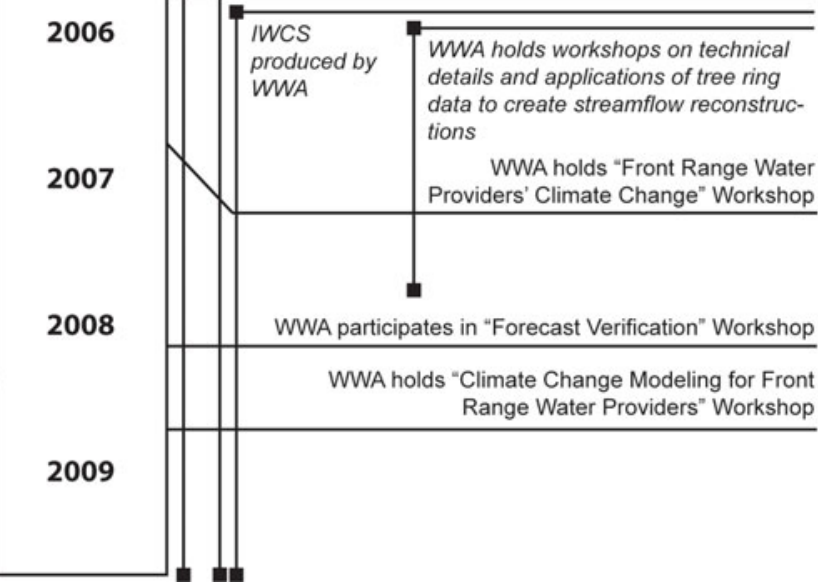

Fig. 1. Timeline of significant climatological events and interactions with Western Water Assessment (WWA) that helped increase water managers' perception of risk, climate literacy, and use of climate information and forecasts. NOAA: National Oceanic and Atmospheric Administration; CU: University of Colorado; WATF: Water Availability Task Force; IWCS: Intermountain West Climate Summary 
example, a water provider who only has water supplies on the west side of the Continental Divide may be more sensitive to water supply shortages than a water provider that has supplies on both the east and west sides of the divide. A provider may be more vulnerable to drought when a water supply shortage or a call for water from a senior water rights holder affects the west side, whereas a provider with supplies on both sides of the Continental Divide may be able to make up for shortages on one side with supplies from the other.

The administration of water rights also affects annual water availability for cities, because available streamflow is allocated to Colorado water users in order of seniority of water rights. Most rivers in Colorado are fully appropriated, i.e. water rights exist to claim all available streamflow during all but the very wettest periods. New water rights holders are allowed to take water in years with anomalously high snowfall in the mountains, which results in high spring runoff, or during extraordinarily large rainstorms.

Most Colorado river basins experience a high degree of annual variability. Water systems across the state have adjusted to annual variability through the use of reservoir storage to carry over water from wet years to dry years. Water providers who hold relatively senior water rights will be able to continue diverting during years with reduced streamflow, and they are not as dependent on reservoir storage as those with more junior water rights. A provider with a 1:1 ratio of reservoir storage to annual demand and no ownership of senior direct flow water rights might have a higher sensitivity to climate variability than a provider whose storage ratio is $2: 1$. One year of below average water supply may cause a significant drawdown of reservoirs in Westminster (1:1 ratio), while Aurora ( 4:1) will be able to carry much more water over from one dry year into another, because it can supply more than one year's demand with water stored in its reservoirs (Table 1). However, Westminster's senior water rights enable diversions even in dry years, while Aurora has more junior water rights, which it must offset with additional reservoir storage space to maintain a reliable supply.

In summary, water managers along the Front Range of Colorado face many challenges in annual operating decisions as they plan several decades ahead to ensure water supply reliability. Their water supplies are inherently sensitive to climate, and a growing population means that they will continue to be vulnerable to droughts that decrease their annual water availability. In the present study, we were able to use established connections between WWA and these water managers in order to observe their interest in climate information and ask them detailed questions about their decision processes and uses of climate products.

\section{METHODS}

This research was conducted between 2004 and 2009 using an 'interactive model' (Lemos \& Morehouse 2005), which strives to facilitate ongoing relationships between researchers and stakeholders in the flow of information in both directions. The goal of the interactive model is to produce usable scientific information, which require stakeholder interactions and interdisciplinarity. According to Lemos \& Morehouse (2005), interdisciplinarity involves 'scientists from different disciplines working together to tackle problems whose solutions cannot be achieved by any single discipline' (2005, p. 62). The multidisciplinary WWA umbrella comprises scientists from social sciences (policy, law, and economics) and physical sciences (atmospheric dynamics, climatology, geology, and hydrology). Our research structure was guided by the explicit needs of the stakeholders (water managers) so that the results meet their informational needs. By understanding our stakeholders' uses and needs for climate information, outlooks, and projections, information providers (e.g. NOAA) can produce more useful climate products and services.

Throughout the study period, we interacted with several water managers from each of the 6 providers via interviews, meetings, and workshops, as well as by considering published accounts on water management during drought periods in this region (Klein \& Kenney 2005, Kenney et al. 2004, 2008; Klein et al. 2007). These water managers possess expertise on annual and long-term operations and management, supply planning and modeling, and demand management/ conservation (Table 2). The interviews conducted specifically for this research took place between 2006 and 2007, although the study involved discussions at meetings and workshops with water providers over a 5 yr period (2004-2009). In addition, since 2004, these providers have received a WWA publication, the 'Intermountain West Climate Summary' 8 times annually, which is intended, in part, to increase climate literacy. This publication provides annotated maps of current and forecasted climate conditions, including streamflows, snowpack, and other information. The goal of these efforts-workshops and the above-mentioned publication - has been to improve water managers' climate literacy so that they can better understand the sensitivity of their water supplies to climate variability and change and take advantage of the climate information, outlooks, and projections provided by NOAA, NRCS, and other such organizations.

We synthesized information from interviews, evaluations of public documents, and informal communications at meetings and workshops. The information obtained from water managers can be grouped into 3 
Table 2. Communication between researchers and study participants during the study period (workshops, interviews, meetings, etc.); includes only those agencies and their staff participating in the present study. WWA: Western Water Assessment

\begin{tabular}{|c|c|c|c|c|}
\hline Date & $\begin{array}{l}\text { Type of communication } \\
\text { (Title) }\end{array}$ & Water provider & $\begin{array}{l}\text { Number of } \\
\text { participants }\end{array}$ & Areas of expertise of participants \\
\hline 27 Aug 2004 & $\begin{array}{l}\text { Presentation (Science-Policy } \\
\text { Assessments for Water } \\
\text { Resource Managers }\end{array}$ & Northern & $\sim 7$ & $\begin{array}{l}\text { Annual water-supply modeling and annual } \\
\text { operations and public relations }\end{array}$ \\
\hline 21 Jan 2005 & $\begin{array}{l}\text { Meeting (Denver Water and } \\
\text { WWA Informational Meeting) }\end{array}$ & Denver & 7 & $\begin{array}{l}\text { Annual operations and long-term } \\
\text { planning management, demand projections/ } \\
\text { management, long-term water-supply projections, } \\
\text { annual water-supply modeling }\end{array}$ \\
\hline Feb/Mar 2005 & $\begin{array}{l}\text { Questionnaire on the } \\
\text { Experimental Southwest } \\
\text { Climate outlooks }\end{array}$ & $\begin{array}{l}\text { Denver, } \\
\text { Northern }\end{array}$ & 3 & $\begin{array}{l}\text { Annual water-supply modeling, } \\
\text { long-term planning and modeling }\end{array}$ \\
\hline 25 Aug 2005 & $\begin{array}{l}\text { Meeting (WWA Demand } \\
\text { and Conservation Pre- } \\
\text { Meeting with Aurora) }\end{array}$ & Aurora & 1 & Demand management/conservation \\
\hline 8 Sep 2005 & $\begin{array}{l}\text { Meeting (Aurora Demand } \\
\text { Meeting) }\end{array}$ & Aurora & 5 & $\begin{array}{l}\text { Annual operations and long-term planning } \\
\text { management, public relations, horticulture, } \\
\text { demand management/conservation, irrigation }\end{array}$ \\
\hline 22 Nov 2005 & $\begin{array}{l}\text { Meeting (Denver Climate } \\
\text { Change Scoping meeting) }\end{array}$ & Denver & 2 & $\begin{array}{l}\text { Annual operations and long-term planning } \\
\text { management, annual water-supply modeling, } \\
\text { long-term planning and modeling }\end{array}$ \\
\hline 1 Dec 2005 & $\begin{array}{l}\text { Workshop (Colorado } \\
\text { Climate Workshop) }\end{array}$ & $\begin{array}{l}\text { Aurora, Boulder, } \\
\text { Colorado Springs, } \\
\text { Denver, Northern, } \\
\text { Westminster }\end{array}$ & 12 & $\begin{array}{l}\text { Annual operations and long-term planning } \\
\text { management, annual water-supply modeling, } \\
\text { demand management/conservation, long-term } \\
\text { planning and modeling }\end{array}$ \\
\hline 9 Feb 2006 & Interview & Denver & 2 & $\begin{array}{l}\text { Annual operations and long-term planning } \\
\text { management, annual water-supply modeling, } \\
\text { long-term planning and modeling }\end{array}$ \\
\hline 24 Feb 2006 & Interview & Northern & 2 & $\begin{array}{l}\text { Annual operations and long-term planning } \\
\text { management, annual water-supply modeling, } \\
\text { long-term planning and modeling }\end{array}$ \\
\hline 3 Mar 2006 & Interview & Westminster & 4 & $\begin{array}{l}\text { Annual water-supply modeling and operations, } \\
\text { long-term planning and modeling, demand } \\
\text { management/conservation }\end{array}$ \\
\hline 31 Jun 2006 & Interview & Boulder & 1 (consultant) & $\begin{array}{l}\text { Consultant on planning for annual operations and } \\
\text { long-term decisions }\end{array}$ \\
\hline 17 Nov 2006 & $\begin{array}{l}\text { Workshop (Front Range } \\
\text { Water Provider Climate } \\
\text { Change Workshop) }\end{array}$ & $\begin{array}{l}\text { Aurora, Boulder, } \\
\text { Colorado Springs, } \\
\text { Denver, Northern }\end{array}$ & $7+$ & $\begin{array}{l}\text { Annual operations and long-term planning } \\
\text { management, annual water-supply modeling, } \\
\text { long-term planning and modeling }\end{array}$ \\
\hline 17 Sep 2007 & Interview & Aurora Water & 9 & $\begin{array}{l}\text { Annual operations and long-term planning } \\
\text { management, annual operations and water } \\
\text { accounting, demand management/conservation, } \\
\text { planning for climate variability, water reuse }\end{array}$ \\
\hline 15 Oct 2007 & Interview & Colorado Springs & 2 & $\begin{array}{l}\text { Annual operations and long-term planning } \\
\text { management, long-term planning and modeling }\end{array}$ \\
\hline 1 Feb 2008 & $\begin{array}{l}\text { Workshop (Climate Change } \\
\text { Modeling for Front Range } \\
\text { Water Providers) }\end{array}$ & $\begin{array}{l}\text { Aurora, Boulder, } \\
\text { Colorado Springs, } \\
\text { Denver, Northern }\end{array}$ & 10 & $\begin{array}{l}\text { Annual operations and long-term planning } \\
\text { management, annual water-supply modeling, } \\
\text { long-term planning and modeling }\end{array}$ \\
\hline 19 Feb 2008 & $\begin{array}{l}\text { Workshop (Forecast } \\
\text { Verification) }\end{array}$ & $\begin{array}{l}\text { Aurora, Denver. } \\
\text { Northern, } \\
\text { Westminster }\end{array}$ & 9 & $\begin{array}{l}\text { Annual operations and long-term planning } \\
\text { management, annual water-supply modeling, } \\
\text { long-term planning and modeling, conservation }\end{array}$ \\
\hline $\begin{array}{l}\text { Dec 2008/ } \\
\text { Jan } 2009\end{array}$ & $\begin{array}{l}\text { Email exchanges (Follow-up } \\
\text { questions from interviews } \\
\text { regarding use of climate } \\
\text { information before } 1997 \text { and } \\
\text { between } 1997 \text { and 2002) }\end{array}$ & $\begin{array}{l}\text { Aurora, Boulder, } \\
\text { Colorado Springs, } \\
\text { Denver, Northern, } \\
\text { Westminster }\end{array}$ & 6 & $\begin{array}{l}\text { Annual operations and long-term planning } \\
\text { management, annual water-supply modeling, } \\
\text { long-term planning and modeling }\end{array}$ \\
\hline
\end{tabular}


categories: perception of risk, decision processes, and climate literacy ${ }^{7}$. We wanted to better understand the perceptions of individual water managers, because decision makers combine personal and subjective assessments of their systems' adaptability and vulnerability to climate variability or change with objective evidence (Ray 2004). Their perceptions include opinions on the vulnerability of a water supply system to shortages due to climate variability, as well as the skill of climate outlooks and projections ${ }^{8}$. During interviews, we asked questions about experiences with climate and weather events and with using climate information to deal with those events (Appendix 1). During discussions at meetings and workshops, we assessed how water managers perceive climate variability and change, and how these perceptions differed among individual water managers. In particular, we wanted to know how water managers perceive that vulnerability to water shortage might change with possible future climate change and how the 2002 drought influenced these perceptions.

We followed the policy sciences framework as described by Lasswell (1956) to assess how water managers use climate information to deal with the effects of climate variability on their water supplies. We identified points in both annual and long-term decisionmaking processes in which climate information, outlooks, and projections either actually or potentially helped water managers make decisions about water availability or demand management. First, we evaluated planning and policy documents, as well as city council meeting minutes, to identify annual and longterm projections, operations, and plans (Appendix 2). We then used open-ended interviews (based on a set of questions) to speak with water managers at, or consultants for, each of the 6 providers (Appendix 1). Through these interviews, we gathered specific information about operational and planning models, decision-making processes, projections, and the uses and needs for climate information. We interviewed people responsible for different parts of the planning process, and identified instances in which climate information is currently being used and in which it potentially could be used, to help increase the reliability of the water supply system to and make better decisions in the future.

Finally, we used an institutional analysis framework (Ingram et al. 1984, Ray 2004) to identify factors that

\footnotetext{
${ }^{7}$ 'Climate literacy' is defined as water managers' knowledge of the climate system and the impact of climate variability on the availability of water relative to annual operating decisions and long-term plans (Niepold \& McCaffery 2008).

${ }^{8}$ 'Skill' of climate outlooks and projections is commonly defined as the degree to which the forecast did better than a reference forecast (i.e. climatology) (Wilks 1995).
}

affect the use of climate information and forecasts in annual and long-term decisions, including the perception of risk, the drought of 2002, and interest in climate variability and change. By hosting meetings and workshops, the WWA has actively tried to improve the climate literacy of water managers throughout the study period, and to analyze how our interactions have affected water managers' use of climate information, outlooks, and projections.

\section{RESULTS AND DISCUSSION}

Our analysis shows that water managers in these 6 agencies now use climate information in both annual operating decisions and long-term (30 to $50 \mathrm{yr}$ ) planning (see Appendix 1, which summarizes all subsequent results except where noted). The results show that the current interest of water providers in climate information, outlooks, and projections was instigated by a severe drought, which elevated their perception of risk. These water managers use current and historic climate data in quantitative annual and long-term water availability and demand models, but they use climate outlooks only qualitatively in non-quantitative annual supply and demand projections (Table 3). They are striving to figure out how to incorporate climate change projections in quantitative models of long-term reliable supply. Since the drought of 2002, which caused water supply shortages across Colorado and created the need for water use restrictions (Appendix 1; Kenney et al. 2004, Pielke et al. 2005), managers of the 6 water providers have increased their use of climate information and projections, as well as their climate literacy (Fig. 1). They have also expressed an interest in additional education on the climate system, natural variability, and the skill and methodology of climate and streamflow forecasts.

\subsection{Water provider perceptions of risk}

The 'perception of risk' is the way a water manager understands the sensitivity of water availability to climate variability and the provider's vulnerability to drought. The water managers surveyed in the present study indicated that they use information gained from their own experiences, anxieties about the uncertainty of the future, and media coverage of climate in order to define the risk their water supply systems face to the threat of a changing climate. The latter assessment includes perceptions of the influence of climate on water supplies or the skill of climate outlooks (Appendix 1). The climate system is not fully understood, and confidence among scientists in the ability 
Table 3. Information (not) used quantitatively by water managers in both annual and long-term decisions. NWS: National Weather Service; NCDC: NOAA National Climatic Data Center; IPCC: Intergovernmental Panel on Climate Change; GCMs: general circulation models; 'exceedance probability': probability that a variable will exceed a given threshold level during a given time period. Other abbreviations, see Appendix 1 legend

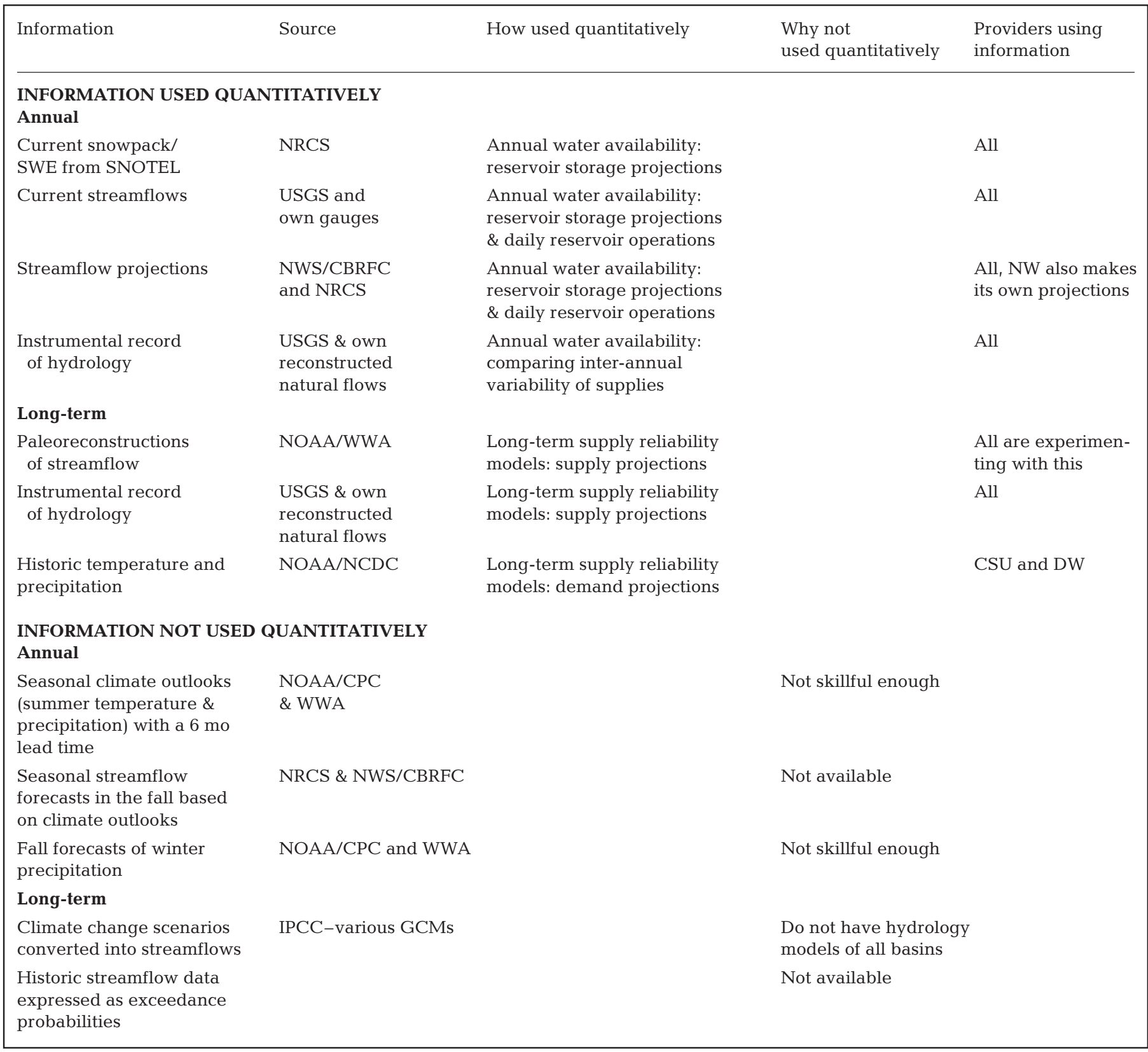

of general circulation models (GCMs) to predict future hydrologic conditions is low (IPCC 2007a), so water managers cannot confidently assess the future vulnerabilities to drought. Many scholars have found that a decision maker's perception of risk is just as important in the crafting of climate-related policy as the results of quantitative risk assessment (Slovic 1987, Dessai et al. 2004, Grothmann \& Patt 2005, Leiserowitz 2005, 2006).

\subsection{Annual versus long-term climate information}

Water managers in Colorado make decisions about water availability and demand in order to address annual operating practices and planning for long-term system reliability. Annual operating decisions include consideration of the number of years associated with the longest drought period contained in the operating criteria or historic record of the water provider. The 
time frame encompassed in annual operating decisions will vary from one water provider to another, based on the seniority of the provider's water rights and the degree to which its water system reliability depends on carry-over of reservoir storage from wet years to dry years. The annual operating decisions ensure a sufficient supply each year for the demands of people, business, industry, or, in Northern Water's case, agriculture, throughout a time frame that might correspond to the number of years expected to be encompassed in a typical dry period. Inputs into these decisions include reservoir storage levels, tunnel and pipeline operations, water treatment, water source selection, and water distribution. Water managers in Colorado are accustomed to dealing with highly variable annual streamflows and have a level of confidence in the ability of water systems to perform as designed based on historic long-term averages. The water managers have an interest in interannual and shorter term conditions to manage water systems for the expected dry periods for which they were designed. During the winter, water managers look at the accumulation of snow in the mountains and estimate how much runoff will be available to divert into reservoirs during the spring and summer. To make annual water availability projections, they use snowpack data from NRCS SNOTEL (snowpack telemetry) gauges throughout the winter, and spring/summer streamflow forecasts from NRCS and National Weather Service Colorado Basin River Forecast Center (NWS/CBRFC). This information is used to estimate annual water supplies and to quantitatively project water availability for reservoir operations in annual operations models that incorporate streamflow forecasts and historic water rights administration.

Long-term decisions or plans involve estimating future population growth and the corresponding water demands and securing adequate water supplies to meet these demands. Securing new supplies enables water providers to take additional water from the streams and rivers, and may include the building of new reservoirs and conveyance systems and the purchasing of existing water rights. These efforts take many decades to accomplish, so water managers typically plan 30-50 yr ahead. As discussed below, long-term decision-making increasingly incorporates information on long-term climate variability and climate change.

Water managers' perception of risk and the climate factors they consider are different for annual operating decisions than for long-term planning. Even though the risk of drought is renewed every year, 1 yr of below average supplies may be mitigated by use of water stored from a previous wetter year or overcome by enforcing water-use restrictions or other demand management strategies. The availability of supplies in one year may affect supplies in the following years, because water managers use reservoir storage to even fluctuations between wetter and drier years. A drought year could be followed by another drought year, a year of abundant supplies, or an average year. Therefore, the risk of annual shortages changes every year, and it can improve or decrease each year depending on the extent to which a particular water system can accommodate the fluctuations of the previous few years. Long-term risk of drought is more enduring, because, if water providers do not prepare adequately for future demands or climate conditions, they will not be able to compensate quickly, resulting in longer periods of water shortages that deplete reservoir reserves and cannot be overcome with demand management policies. The water managers in the present study have a longer history of using climate outlooks for annual operating decisions than of using climate projections for long-term planning. From their perspective, the likelihood of a single year deviating from the historic average short term can be relatively well defined, whereas significant uncertainty exists regarding the degree to which the climate in the future may vary from the average at present.

\subsection{Use of climate information, outlooks, and projections before 2002}

\subsubsection{In annual operating decisions}

To assist with annual operating decisions, NOAA climate scientists within the WWA began interacting with water managers along the Colorado Front Range in 1997 (Appendix 1) and providing forecasts of the El Niño event with meetings and informational packets. At that time, water providers were looking at historic gauge records of streamflows in their water supply basins to get an idea of the potential variability of their annual water supplies. Several providers regularly consulted the United States Drought Monitor, monitored United States Geological Survey (USGS) streamflow gauges, and used winter and spring/summer streamflow forecasts from the NRCS and CBRFC (Appendix 1).

\subsubsection{In long-term planning}

For long-term planning, most water providers relied on the design basis for which the greatest amount of reliable data existed by assuming that future water supply variability would be similar to the historic record of streamflows. Prior to the 1990s, only 2 of the water providers (Denver and Northern) were actively 
investigating the use of paleo-reconstructed streamflows (Appendix 1), which provide information on the range of natural variability of past droughts that were longer or more severe than any experienced in the $100+$ yr of the historic record. Between water years ${ }^{9}$ 1997 and 2000, water supplies were average or above average (Colorado Division of Water Resources 19972000, http:water.state.co.us/pubs/swsi.asp; McKee et al. 1999), and WWA found that most water managers did not look at seasonal climate outlooks or climate change projections. Instead they used historic streamflows and current water supply/snowpack data to assess their annual vulnerability to drought (Lewis 2003).

\subsection{Use of climate information, outlooks and projections after 2002}

\subsubsection{In annual operating decisions}

Beginning in 2002, all 6 water providers indicated that they increased their use of climate information, outlooks, and projections in both annual operations and long-term planning decisions relative to the time period before the drought. To calculate annual water demand, these water managers previously used historic data on water use per capita, accounting for any new or anticipated development. However, because at least $50 \%$ of the annual municipal water use is for outdoor lawn irrigation (Mayer et al. 1999), several providers have attempted to account for the impact of climate on water demand. Beginning in or after 2002, all 6 water managers started considering seasonal climate outlooks issued monthly by NOAA/CPC and regional experimental seasonal guidance products from WWA in order to qualitatively anticipate above average summer demands. Summer demand information is especially important during years of below average snowpack and/or below average streamflow projections. These water managers also consider seasonal climate outlooks to anticipate times of low water supply, but this is only a qualitative use; they do not input any climate forecast information into the models.

The 4 reasons given by the 6 study participants for not using climate outlooks quantitatively are consistent with the reasons given in previous studies (Callahan et al. 1999, Pagano et al. 2001, 2002, Hartmann et al.

\footnotetext{
${ }^{9} \mathrm{~A}$ water year is the 12 mo period from 1 October through 30 September. The water year is designated by the calendar year in which it ends; thus, the year ending on 30 September 1997 is called the 1997 water year. It commences with the start of the season of soil moisture recharge and includes the season of maximum runoff (American Meteorological Society Glossary of Meteorology, http://amsglossary.allenpress. com/glossary/browse? $\mathrm{s}=\mathrm{w} \& \mathrm{p}=10$; accessed on 3 August 2009).
}

2002, Carter \& Morehouse 2003, Gamble et al. 2003, Rayner et al. 2005, Steinemann 2006). (1) Climate outlooks do not provide information on the appropriate scale. Climate outlooks are designed for climate divisions, not for river basins or watersheds, which is the scale water managers use for streamflow forecasts. (2) Climate outlooks provide information about temperature and precipitation, not streamflows. To date (2009), these water managers do not use specialized water system operational models that can convert temperature and precipitation into streamflows. Typically, most operational water system models are constructed to use streamflow data and would need to be modified to bring in temperature and precipitation data, adequately correlate these data to historic streamflow data, and reliably project future streamflow. (3) Verification information about climate outlooks does not meet their needs. Many water managers do not understand skill scores or know the difference between skill and accuracy ${ }^{\mathbf{1 0}}$. (4) Water managers take the consistent aboveaverage temperature and EC ('equal chances') precipitation forecasts for the Intermountain West Region 11 (Livezey \& Timofeyeva 2008) to mean there are no forecasted anomalies. Despite these limitations, water managers look at and discuss seasonal outlook and incorporate their impressions into 'mental models,' which combine objective evidence of current snowpack and streamflow conditions with a subjective assessment of their systems' reliability (Appendix 1).

\subsubsection{In long-term planning}

Most providers are planning ahead to 2030 and/or 2050 (Appendix 1). Such long-term planning involves ensuring system reliability as the water demand and population grow, which traditionally means acquiring additional water supplies. The amount of new water supplies needed is based on how much water demand and population are anticipated to grow (i.e. expected time to build out). Cities like Aurora and Colorado Springs, which have plenty of physical room to expand, would need to acquire more water than providers in Denver and Westminster, which are physically blocked from expanding due to the surrounding suburbs. Northern Water, while not physically expanding, will need to acquire more water to supply cities

\footnotetext{
10 'Accuracy' is the degree to which the forecast corresponds to what actually happened, whereas 'skill' is the degree to which the forecast did better than a reference forecast (i.e. climatology) (Wilks 1995)

11 According to the Forecast Evaluation Tool, a precipitation forecast was only made one-fourth to one-third of the time for the winter (snow fall) months (http://fet.hwr.arizona. edu/ForecastEvaluationTool/)
} 
that are continuing to grow. Assuming continued population growth, the annual water demand of all the water providers in the present study will continue to increase in the next 20 to 40 yr (Appendix 1).

All 6 water providers use supply reliability models to evaluate historic water supplies against future demands and to ensure a reliable water supply under a range of climate conditions (Appendix 1). These models project future water demands onto the instrumental record of streamflows and reservoir storage, which includes the range of climate variability from the recent past. Since 2002, all 6 water managers considered in the present study have expressed an interest in paleo-reconstructed streamflows created from treerings, in order to increase the range of climate variability data for use in their long-term models. These reconstructions include longer and more severe droughts than indicated by the instrumental record (Woodhouse \& Lukas 2006). Several managers already have or are trying to incorporate paleo-reconstructed streamflows into their models, but this has proven complicated due to differing time scales: the reconstructed streamflows are on an annual basis and the models require weekly or monthly values (Appendix 1).

\subsection{Changes surrounding the 2002 drought}

Interest in and understanding of climate by water managers has increased through the study period (Appendix 1). Beginning in 1998 and continuing through the study period, the water managers considered here have attended many workshops and meetings co-organized by NOAA and WWA. These workshops had 2 purposes: (1) to educate water managers on topics such as seasonal forecasting, climate variability and change, paleo-reconstructions of streamflows, forecast verification, and climate change modeling and (2) to improve climate scientists' understanding of water resource decision-making as part of a process to identify opportunities for new climate information to meet the needs of water managers (Fig. 1). Most of these workshops occurred after the 2002 drought, in parallel with a renewed interest in the WATF. During the 2002 drought, WWA conducted 'rapid-response' efforts to inform and educate water managers, including regularly updating summaries of current climate information and outlooks. These summaries were distributed as information sheets at stakeholder meetings such as those of the WATF and during discussions at conferences.

With their improved climate literacy, water managers along the Front Range of Colorado have started to use climate information, outlooks, and projections in new ways, as well as to fund research to develop more useful climate products (Fig. 1). Boulder, Denver, Northern and Westminster now incorporate tree-ringreconstructed streamflows into long-term supply reliability models, in order to extend the range of their knowledge on historic climate variability. In Boulder, formal drought plans use climate-related variables like snowpack and projected reservoir storage to 'trigger' different stages of drought and associated water use restrictions. This approach allows water managers to ensure that demand will not exceed supply if water shortages are expected. Water managers also require a better understanding of the skill of forecasts, including seasonal climate outlooks, streamflow forecasts, and long-term climate change projections. To accomplish this they need to understand both forecast methodology and verification techniques. In February 2008, WWA co-hosted a workshop on streamflow forecast verification with NWS and NRCS to meet this need.

For long-term planning, providers are beginning to pay close attention to climate change projections and are trying to incorporate them into long-term supply reliability models. Since 2006, both Aurora and Denver have hired climate change scientists to specifically address this issue. Boulder has worked with 2 private companies (Stratus Consulting and AMEC) to complete a study of the potential effects of climate change on its water supplies, which was partially funded by NOAA. Water managers in Colorado are working together to use climate information in water supply planning. Collaboration among water providers on water supply planning and climate is unprecedented in Colorado. Since 2007, a project funded by WWA, AMEC, and 4 Front Range cities (Aurora, Boulder, Colorado Springs, and Denver) has been developing a model that uses climate variables to find analogue years of streamflows and to create ensemble forecasts of management variables like reservoir storage. In 2008, Boulder completed a climate change study that used climate change projections to assess the longterm variability of Boulder's water supplies. Also in 2008, water managers from 6 providers (Aurora, Boulder, Fort Collins, Colorado Springs, Denver, and Northern) began funding the Joint Front Range Climate Change Vulnerability Study on the impact of climate change on the water resources in Colorado; this study will use downscaled projections of changes in temperature and precipitation from GCMs in regional hydrologic models (Appendix 1).

\subsection{Information exchange between decision makers and climate information providers}

Throughout the study period, as interactions with climate information providers helped improve climate 
literacy among water managers (Fig. 1), we have seen how water managers have also informed climate scientists on needs for additional research. The water managers considered in the present study have specific needs for climate information, outlooks, and projections, and they had insightful suggestions about different or additional information products and services. The bottom half of Table 3 shows specific types of climate outlooks, projections, and streamflow forecasts that water managers desire but that are not currently available or skillful enough. In addition, water managers had a number of specific ideas for climate education, data, and services for the climate science community to provide to increase climate literacy:

(1) Improved availability and utility of climate information and natural variability

- Effect of climate patterns (e.g. ENSO) on regional weather.

- Regional trends in temperature, precipitation, and streamflows; compare anomalous years to natural variability.

- Reoccurrence interval of single- and multi-year droughts and other extremes.

- Regional variability in historic streamflows among river basins (exceedance probabilities); reliability of current or future water rights.

(2) Improved communication of climate forecast methodology and skill

- Underlying assumptions and uncertainties of forecast models

- Sources of forecast and data error

- Verification methods, including hindcasting

- Types of verification (resolution/sharpness vs. reliability)

- Skill versus accuracy

- Regional patterns of skill

These results are consistent with a recent federal interagency perspective on climate change and water resource management (Brekke et al. 2009).

Due to the nature of their work water managers have an interest in climate information and a better understanding of climate systems than the average member of the public. An increased understanding of the availability and utility of climate information and natural variability will help water managers comprehend and use climate information, as well as place anomalous years in a historical perspective. For annual operating decisions, water managers would like streamflow forecasts for the South Platte and Arkansas Rivers, similar to those available for the Colorado River. They require a better understanding of the connections among snowpack, soil moisture, other climate variables like temperature, and streamflows, and they recommend research in these areas that would enable more accurate and possibly earlier streamflow forecasts. Also needed are more skillful spring and summer streamflow forecasts and precipitation outlooks in the fall in order to give water managers an earlier assessment of water availability for the following year and to allow lead time for planning any necessary water use restrictions.

For long-term planning, water managers want to learn more about the difference between natural variability and climate change projections, especially as climate change projections translate into streamflows. They want to know how climate change may affect the timing and volume of streamflows and water rights administration in the future. In addition to education efforts, a research priority should be to quantify the relationship among weather variables (snowpack, soil moisture, temperature, and precipitation) and streamflow in order to increase the accuracy of seasonal streamflow forecasts. NRCS in Utah has already begun this kind of research (Julander \& Perkins 2004), and water managers are willing to fund the installation of new soil moisture sensors. Finally, the water managers considered in the present study supported increased monitoring of precipitation by expanding the SNOTEL observation network because a more accurate understanding of current climate will lead to a better understanding of possible changes that are occurring and are projected to occur.

\section{CONCLUSIONS}

Water managers along the Colorado Front Range use a variety of climate information, outlooks, and projections in annual operating decisions and long-term plans. In general, the water managers considered in the present study use climate information quantitatively in annual operating decisions and long-term decision models, use seasonal climate outlooks qualitatively in annual operating decisions, and are beginning to use climate change projections to assess future vulnerability to drought. They look at seasonal climate outlooks and climate change projections, but for the most part they do not use them quantitatively due to inadequate skill, spatial and temporal scales, or lack of variables (i.e. monthly streamflows) that are needed as input to their models. Throughout the study period, we observed an increased interest in climate information, outlooks, and projections as the water managers improved their climate literacy. Water managers are now able to articulate the specific kinds of climate information, outlooks, and projections they need in order to better use the quantitative results from these climate products in their annual operations and longterm decision models. Thus, climate professionals are developing an increased interest in the factors affect- 
ing management of water systems and the types of climate information that may be useful in supporting water manager decision-making.

We attribute this increased interest in climate and desire to improve climate literacy to an elevation in perception of risk that occurred as a result of the severe drought in 2002. The drought experience appears to be a focusing event (Birkland 1998, Pulwarty et al. 2005) during which water managers' perception of risk shifted as they realized that their water supply systems may not be reliable if they only plan for droughts similar to those that have occurred in the historic record. This experience increased water managers' anxiety over a possible future in which water shortages may occur with a different pattern or frequency than in the past. Subsequently, they sought out new sources of climate information and education, leading to improved climate literacy and increased use of climate products. Despite concerns with climate outlooks and projections, water managers along the Front Range of Colorado want to learn how they can increase their use of climate outlooks and projections to make their systems more reliable in the face of possible changing climate variability. This evolutionary increase in interest in climate information among Colorado Front Range water providers parallels many of the responses documented by Power et al. (2005) in reaction to the prolonged drought in Western Australia. In both cases, improved understanding of possible climate impacts, as well as access to and increased familiarity with climate information and products, resulted in decision makers considering risks associated with climate influences on supply and demand in their planning processes.

The interactions between WWA and water managers before and throughout this critical time of shifting perceptions helped foster these changes. Scientists and climate information providers helped elevate water managers' perception of risk by increasing climate education efforts through workshops, meetings, and publications specifically developed for water resource decision makers. Improved climate literacy enabled water managers to understand the benefits of using climate information and forecasts in annual and longterm decisions. Another outcome was an improved understanding by climate specialists of the operational factors affecting water managers' decisions such as water rights limitations, sensitivity to seasonal aspects of precipitation, and the need for translation of temperature and precipitation data into streamflow data. Our study confirms the value of the co-production of knowledge (Ostrom 1999) that results in climate science informing but not prescribing decision-making, and decision-making informing climate science but not prescribing research priorities. Climate informa- tion providers, such as WWA and other RISA programs, should continue and increase these partnership efforts in education and outreach. Through regular communication, we can help water mangers increase their understanding of climate systems, how forecasts are made, and the current limitation of seasonal and longer forecasts. Regular communication will also improve the understanding that climate information providers have of water system operations and the type and format of climate information that is of use to water managers. Armed with that information, water managers and climate professionals will be better suited to combine their technical expertise on water supply and management with climate information, outlooks, and projections to adapt to a changing climate, to increase the reliability of their water availability, and to manage demand now and in the future.

Acknowledgements. The authors are grateful to K. B. Averyt for her advice and editing assistance, to N. Doesken for information on the history of the WATF, and to D. S. Kenney, R. Klein, and R. S. Pulwarty for editing versions of this manuscript. Funding to support this research came from the NOAA Climate Programs Office to the Western Water Assessment and the NOAA Office of Oceanic and Atmospheric Research.

\section{LITERATURE CITED}

Birkland TA (1998) Focusing events, mobilization, and agenda setting. J Public Policy 18:53-74

Brekke LD, Kiang JE, Olsen JR, Pulwarty RS and others (2009). Climate change and water resources management: a federal perspective. U.S. Geological Survey Circular 1331, USGS, Reston, VA

Callahan B, Miles E, Fluharty D (1999) Policy implications of climate forecasts for water resources management in the Pacific Northwest. Policy Sci 32:269-293

Carter RH, Morehouse BJ (2003) Climate and urban water providers in Arizona: an analysis of vulnerability and perceptions and climate information use. CLIMAS Report Series CL:1-03, Institute for the Study of Planet Earth, University of Arizona, Tucson, AZ

CCSP (Climate Change Science Program) (2008) Decisionsupport experiments and evaluations using seasonal-tointerannual forecasts and observational data: a focus on water resources. In: Beller-Simms N, Ingram H, Feldman D, Mantua N, Jacobs KL, Waple AM (eds) A report by the U.S. Climate Change Science Program and the subcommittee on global change research. NOAA National Climatic Data Center, Asheville, NC

Dessai S, Adger WN, Hulme M, Turnpenny J, Kohler J, Warren R (2004) Defining and experiencing dangerous climate change. Clim Change 64:11-25

Gamble JL, Furlow J, Snover AK, Hamlet AF, Morehouse BJ, Hartmann H, Pagano T (2003) Assessing the impact of climate variability and change on regional water resources: the implications for stakeholders. In: Lawford R, Fort D, Hartmann HC, Eden S (eds) Water: science, policy, and management. American Geophysical Union, Washington, DC, p 341-368 
Grothmann T, Patt A (2005) Adaptive capacity and human cognition: the process of individual adaptation to climate change. Glob Environ Change 15:199-213

Hartmann HC, Pagano TC, Sorooshian S, Bales R (2002) Confidence builders: evaluating seasonal climate forecasts from user perspectives. Bull Am Meteorol Soc 83:683-698

Hunter T, Tootle GA, Piechota TC (2006) Oceanicatmospheric variability and western U.S. snowfall. Geophys Res Lett 33:L13706, doi: 10.1029/2006GL026600

Huppert D, Kaje J, Hamet AF, Miles EL, Snover AK (2002) Applications of climate forecasts in natural resources management: implications for industry. In: Golnarghi M (ed) The climate report, Vol 3. Climate Risk Solutions, Brookline, MA, p 12-22

Ingram HM, Mann DE, Weatherford GD, Cortner HJ (1984) Guidlines for improved institutional analysis in water resources planning. Water Resour Res 20:323-334

IPCC (Intergovernmental Panel on Climate Change) (2007a) Climate change 2007: the physical science basis. In: Solomon S, Qin D, Manning M, Chen Zand others (eds) Contribution of Working Group I to the 4th Assessment Report of the Intergovernmental Panel on Climate Change. Cambridge University Press, New York, NY

IPCC (Intergovernmental Panel on Climate Change) (2007b) Climate change 2007: impacts, adaptation and vulnerability. In: Parry L, Canziani OF, Palutikof JP, van der Linden PJ, Hanson CE (eds) Contribution of Working Group II to the 4th Assessment Report of the Intergovernmental Panel on Climate Change. Cambridge University Press, Cambridge

Julander R, Perkins T (2004) Soil moisture data collection and water supply forecasting. U.S. Conference on Irrigation and Drainage, Salt Lake City, UT, October 13-16, 2004. Proc Water Manage Conf on Water Rights, US Committee on Irrigation and Drainage, Denver, CO, p 457-465

Kenney D, Klein R, Clark M (2004) Use and effectiveness of municipal water restrictions during drought in Colorado. J Am Water Resour Assoc 40:77-87

Kenney DS, Goemans C, Klein R, Lowrey J, Reidy K (2008) Residential water demand management: lessons from Aurora, Colorado. J Am Water Resour Assoc 44:192-207

Klein R, Kenney D (2005) Use of climate information in municipal drought planning in Colorado. Western Water Assessment Report WWA01-06, Western Water Assessment, University of Colorado, Boulder, $\mathrm{CO}$

Klein R, Kenney D, Lowrey J, Goemans C (2007) Factors influencing residential water demand: a review of the literature. Western Water Assessment Work Pap V 1.12.07, Western Water Assessment, University of Colorado, Boulder, $\mathrm{CO}$

Lasswell HD (1956) The decision process: seven categories of functional analysis. Bureau of Governmental Research and College of Business and Public Administration, University of Maryland, College Park, MD

Leiserowitz AA (2005) American risk perceptions: Is climate change dangerous? Risk Anal 25:1433-1442

> Leiserowitz A (2006) Climate change risk perception and policy preferences: the role of affect, imagery, and values. Clim Change 77:45-72

> Lemos MC, Morehouse BJ (2005) The co-production of science and policy in integrated climate assessments. Glob Environ Change 15:57-68

Lewis WM Jr (2003) (ed) Water and climate in the western United States. University Press of Colorado, Boulder, CO

- Livezey RE, Timofeyeva MM (2008) The first decade of longlead US seasonal forecasts - insights from a skill analysis. Bull Am Meteorol Soc 89:843-854
Mayer PW, DeOreo WB, Opitz EM, Kiefer JC, Davis WY, Dziegielewski B, Nelson JO (1999) Residential end uses of water. American Water Works Association Research Foundation, Denver, CO

McKee TB, Doesken NJ, Kleist J (1999) Historical dry and wet periods in Colorado. Climatology Report 99-1, Department of Atmospheric Science, Colorado State University, Fort Collins, CO

Nichols PD, Kenney DS (2003) Watering growth in Colorado: swept along by the current or choosing a better line? Univ Denver Water Law Rev 6:411-452

Niepold F, McCaffery MS (2008) Essential principles of climate literacy. NOAA Climate Program Office, Silver Spring, MD. Available at: http://climateliteracynow.org/ files/Climate_Literacy_K-12.pdf (accessed 22 September 2008)

O'Conner RE, Yarnal B, Neff R, Bord R and others (1999) Weather and climate extremes, climate change, and planning: views of community water system managers in Pennsylvania's Susquehanna River Basin. J Am Water Resour Assoc 35:1411-1419

> O'Lenic EA, Unger DA, Halpert MS, Pelman KS (2008) Developments in operational long-range climate prediction at CPC. Weather Forecast 23:496-515

Ostrom E (1999) Crossing the Great Divide: coproduction, synergy, and development. In: McGinnis MD (ed) Polycentric governance and development: readings from the workshop in political theory and policy analysis. University of Michigan Press, Ann Arbor, MI, p 346-374

> Pagano TC, Hartmann HC, Sorooshian S (2002) Factors affecting seasonal forecast use in Arizona water management: a case study of the 1997-98 El Niño. Clim Res 21: 259-269

> Pagano TC, Hartmann HC, Sorooshian S (2001) Using climate forecasts for water management: Arizona and the 19971998 El Niño. J Am Water Resour Assoc 37:1139-1153

> Pielke RA Sr, Doesken N, Bliss O, Greeen T and others (2005) Drought 2002 in Colorado: an unprecedented drought or a routine drought? Pure Appl Geophys 162:1455-1479

Power S, Sadler B, Nicholls N (2005) The influence of climate science on water management in Western Australia. Bull Am Meteorol Soc 86:839-844

Pulwarty RS, Jacobs KL, Dole RM (2005) The hardest working river: drought and critical water problems in the Colorado River basin. In: Wilhite DA (ed) Drought and water crises: science, technology, and management issues. CRC Press, Boca Raton, FL, p 249-285

Ray AJ (2004) Linking climate to multi-purpose reservoir management: adaptive capacity and needs for climate information in the Gunnison Basin, Colorado. PhD dissertation, University of Colorado, Boulder, $\mathrm{CO}$

Ray AJ, Barsugli JJ, Averyt KB, Wolter K and others (2008) Climate change in Colorado: a synthesis to support water resources management and adaptation. Report by the Western Water Assessment for the Colorado Water Conservation Board, Denver, CO

Rayner S, Lach D, Ingram H (2005) Weather forecasts are for wimps: why water resource managers do not use climate forecasts. Clim Change 69:197-227

Serreze MC, Clark MP, Armstrong RL, McGinnis DA, Pulwarty RS (1999) Characteristics of the western United States snowpack from snowpack telemetry (SNOTEL) data. Water Resour Res 35:2145-2160

Slovic P (1987) Perception of risk. Science 236:280-285

Steinemann AC (2006) Using climate forecasts for drought management. J Appl Meteorol Climatol 45:1353-1361

U.S. Department of Interior (2005) Water 2025: preventing 
crises and conflict in the west. U.S. Department of Interior, Bureau of Reclamation, Washington, DC

Wilks D (1995) Statistical methods in the atmospheric sciences: an introduction. Academic Press, London

Woodcock SJ, Thiemann M, Brazil LE, Vincent E, Pineda A (2006) Fraser River extended streamflow prediction system for the Windy Gap Project. In: Zimbelman D, Loehlein
WC (eds) Operating reservoirs in changing conditions. Proc Operations Management Conference, Environmental and Water Resources Institute (EWRI) of ASCE, Sacramento, CA

Woodhouse CA, Lukas JJ (2006) Multi-century tree-ring reconstructions of Colorado streamflow for water resource planning. Clim Change 78:293-315

Appendix 1. Synthesis of information gained from interviews and informal communication with water managers in the present study between 2004 and 2009. Providers-AW: Aurora Water; B: City of Boulder Water Utility; CSU: Colorado Springs Utilities; DW: Denver Water; NW: Northern Water; WWR: City of Westminster Water Resource and Treatment Division; organizations-NOAA: National Oceanic Atmospheric Administration; NRCS/CBRFC: Natural Resources Conservation Service Colorado Basin River Forecast Center; WATF: Water Availability Task Force; WWA: Western Water Assessment; USGS: United States Geological Survey; SWE: snow water equivalent; CPC: Climate Prediction Center; IWCS: Intermountain West Climate Summary; SNOTEL: snowpack telemetry; SNODAS: Snow Data Assimilation System; 'build out': extent of residential, commercial and industrial development in a given geographic area, usually related to the upper limit of population to be served by water resource development; 'firm annual yield': yearly amount of water that can be supplied dependably from the raw water sources of a water supply system

Question Response

How did you use climate information before the 1997 El Niño and between 1997 and 2002?

When did your organization begin to use the historic gauge streamflow record in your long-term planning models or decisions?

When did your organization learn of paleo-reconstructions of streamflows, and when did you attempt to incorporate this information into long-term planning decisions?

When did your organization begin to attend the WATF?

When did your organization first begin to consider seasonal climate outlooks, the drought monitor, etc.?

When do you recall first learning about the WWA and/or interacting with us?

\section{What annual projections does your organization make?}

Do you project sources of spring runoff or annual streamflows?

Do you make projections of reservoir storage each year, including estimations of the time when your storage reservoirs will fill?

Do you calculate annual demand each year and, if so, how do you calculate it?

Do you use other data sources? mental.
All providers have been using historic streamflow records for as long as they can remember to make subjective decisions about annual and long-term water supplies. More recently, as they have developed models of water rights and water supply systems, they have used the stream gauge record in a more quantitative way.

All providers had heard of paleo-reconstructions before 2002, largely due to outreach efforts by local NOAA researchers (Woodhouse). Two providers had heard of paleoreconstructions before Woodhouse's efforts in the 1960s/1970s/1980s (DW, NW). Four have been using them in long-term models since 2009 (B, DW, NW, WWR). The remaining 2 (AW, CSU) plan to use them in future long-term plans.

Water providers have fuzzy memories of when they or someone else at their organization began attending WATF, but they all recalled a new or renewed interest during and since the 2002 drought.

None of the water managers use these products in a quantitative way in their decisions, but they all look at these products for subjective assessments of drought, annual water supplies, and demand. Half have begun to consider these since 2002 (AW, CSU, NW), 1, between 1997 and 2002 (B), and 2, before 1997 (W: 1980s; DW: mid-1990s).

Water managers are fuzzy about their first encounters with WWA, but the majority of them are sure it was after 2002 (B: late 1990s).

All use streamflow forecasts from NRCS/CBRFC data and monitor streamflows using own gauges or those of the USGS. DW and NW also make their own projections. DW and WWR also look at NW's projections.

All use streamflow forecasts, water rights, SWE, and current reservoir storage to obtain a qualitative impression. DW and CSU use models that give a more accurate estimate of reservoir storage. Others use data and experience to make projections.

Mostly based on average per capita water use, increased when there is new development. WWR calculates future annual water demand based on observed water use for land-use types. CSU and DW use a model that accounts for temperature and precipitation. NW's projections are based on water availability, because their water is supple-

All look at NOAA/CPC seasonal climate outlooks, WWA experimental seasonal forecast guidance, and/or medium-range precipitation forecasts, but only use the information qualitatively. Most read IWCS and/or attend WATF meetings to get more information. 
Appendix 1 (continued)

Question

Response

\section{What are your annual operations and planning for these?}

Do you run reservoir and tunnel operations for water supply?

Do you run reservoir operations for hydroelectric power?

Do you carry out reservoir releases on the basis of endangered species, senior water rights, contracts, exchanges, leases, etc.?

Do you determine the necessity of drought-year operations, including restrictions?

\section{What are your long-term projections and plans?}

How much more water do you expect to need for build out? When do you estimate you will reach build out?

What are your long-term future projections regarding annual water demand for treated water, annual supply availability, and the firm yield of reservoirs based on future supplies?

What are your information sources for these projections?

How do you evaluate the reliability of future water supply options?

Have you considered using treering reconstructions of past stream-flows to determine the water supply reliability in your area under different drought scenarios?
All own and operate reservoirs. All operate multiple reservoirs and use transbasin water. AW, CSU, and NW use water from/operate reclamation transmountain projects. B gets their transbasin water from NW, and WWR gets transbasin water from DW.

B, DW, and NW produce hydropower from their reservoirs; it is a secondary use of the water. Water is never released just for hydropower. CSU produces hydropower locally when water is delivered to treatment plants from local and terminal storage reservoirs.

All must operate for senior water rights: AW and CSU have many exchanges; WWR has few. NW, B, and WWR must use bypass flows for senior water users. DW has contracts to provide untreated water to several entities, including WWR. DW has endangered species requirements on the Colorado River.

All except NW have drought plans with triggers that use streamflow forecasts, snowpack, reservoir storage, and/or projected reservoir storage, to determine the necessity of drought restrictions.

All except B are in the process of acquiring more water or more storage space for water. Several are expanding re-use operations.

A range of times until build out is expected. DW, B, and WWR are closer to build out; AW and CSU are still growing. NW is only growing because the cities are growing. Most cities plan for 2030, 2050, or both. DW, B, and WWR have a better idea of the specific amounts of water they will need at build out.

Projections for demands come from anticipated growth, usually from a land-use plan created by a different department with limited or no input from water resources. Projections for supplies: DW, CSU, WWR, and B have models that use past hydrology to determine supply reliability under future demands.

Demand projections from land-use plans, supply projections from hydrologic record, internal demand-side management and conservation planners, and water rights administration.

Most water suppliers use hydrologic records and make sure water supplies will be reliable in a 2050s drought or, at least, able to meet basic demands with the use of restrictions. B uses sophisticated reliability standards, projecting how often different types of drought restrictions will be necessary.

All have looked into this method and would like to use it. Their models cannot use the data directly because they need weekly or monthly, not annual, flows. Water providers are actively pursuing this because they feel more comfortable using long-term reconstructions of the past than uncertain projections of the future to determine whether their water supplies will be reliable.

Do you have any recommendations on how climate outlooks and other products could be improved so that you could use them in annual operations and long-term planning?

Annual operations

Streamflow forecasts for the South Platte and Arkansas Rivers similar to those available for the Colorado River. Better understanding of the connection between snowpack, soil moisture, and streamflows, to obtain more accurate streamflow forecasts; more skillful precipitation outlooks earlier in advance (forecasts for winter precipitation in the fall; accurate 1 Apr snowpack in fall; leading to earlier streamflow forecasts); use of additional variables in streamflow and reservoir forecasts (like the hydrosphere forecasting project for water utilities). For demand, a better understanding of the relationship between climate variables and demand, so that seasonal climate outlooks can be used to determine whether the demand will be different from average.

Long-term planning

A better understanding of the interactions between climate variables (snowpack, temperature, soil moisture, etc.), streamflows, and demand. The relationship of climate variables to forest conditions. Climate-change scenarios turned into hydrologic scenarios (like the Joint Front Range Climate Change Vulnerability Project). How climate change will affect water rights and timing of streamflows, as well as volume. A better understanding of natural variability vs. climate-change projections. More data on precipitation (expand SNOTEL network; improve SNODAS). 
Appendix 2. Public documents from each water provider that the researchers reviewed for information about annual and long-term decision processes. IGA: Intergovernmental Agreement

\author{
Aurora \\ Water Management Plan (2007) \\ Rocky Mountain News article regarding exchanges of Col- \\ orado River Basin water with Eagle Park Reservoir Co \\ (18 Jun 2004) \\ City council meeting minutes (7 Feb 2005) \\ City council meeting minutes (8 Aug 2005) \\ Bureau of Reclamation document asking for comments on \\ the scope of an EA regarding use of excess capacity in the \\ Fry-Ark Project (Sep 2003) \\ Bureau of Reclamation Scoping Report regarding the use of \\ excess capacity in the Fry-Ark Project (Mar 2004) \\ USBR Great Plains NEPA report website \\ Aurora Utilities press release (21 Mar 2005) \\ Denver Water 'Waterwire' article on Chatfield Reservoir \\ City council meeting minutes (21 Mar 2005) \\ IGA document (May 2004) and Water Chat article (25 May \\ 2004) \\ City council meeting minutes (25 Apr 2005) \\ Agenda for a city council study session on 8 Aug 2005 \\ Boulder \\ Drought Plan, Vols 1 \& 2 (2003)

\section{Colorado Springs} \\ 1 Mar IGA (IGA 2-04.pdf) and Colorado Springs Utilities \\ news release (10 Feb 2004) \\ Colorado Springs Utilities Southern Delivery System Fact \\ Sheet (Jan 2004) and Southern Delivery System EIS \\ newsletter from USBR (Sep 2004) \\ IGA document regarding IGA with City of Aurora, City of \\ Pueblo, Board of Water Works of Pueblo, southeastern
}

Colorado WCD, City of Fountain, and Colorado Springs Utilities (May 2004)

Water Chat article (25 May 2004)

\section{Denver}

Moffat Final Purpose and Need Statement (Apr 2004)

Water Watch Report (27 Nov 2006)

2002 Integrated Resource Plan (Feb 2002)

Drought Response Plan (Jun 2004)

\section{Northern}

Vincent E (1999) Streamflow forecast model using weighted snowpack averages. MS thesis, ENSHMG, Grenoble

Brazil et al. (2005) Frasier River extended streamflow prediction system

Waternews (Apr 2005)

Annual Carryover Program rules (Aug 2004)

Windy Gap Firming Project fact sheet (Dec 2004)

WGFP Alternative Plan Executive Summary (Feb 2003)

USBR WGFP Project Update (Dec 2004)

'NISP NEWS' newsletter Vol 2, No 1 (Mar 2004)

NISP Phase II Alternative Evaluation (Jan 2004)

NISP Scoping Report (Mar 2005)

HWY 287 meeting handout, NCWCD, CDOT and USACE (Mar 2005)

Woodcock et al. (2006)

\section{Westminster}

Lang, JL (2003) Westminster water use restrictions 2003: an evaluation of the intelligence decision process. Unpubl. graduate term paper, Environmental Studies, University of Colorado, Boulder
Editorial responsibility: Bryson Bates,

Wembley, Western Australia, Australia
Submitted: March 9, 2009; Accepted: August 9, 2009

Proofs received from author(s): October 10, 2009 